\title{
Time series of vertical flux of zooplankton fecal pellets on the continental shelf of the western Antarctic Peninsula
}

\author{
Miram R. Gleiber ${ }^{1, *}$, Deborah K. Steinberg ${ }^{1}$, Hugh W. Ducklow ${ }^{2}$ \\ ${ }^{1}$ Virginia Institute of Marine Science, Gloucester Point, Virginia 23062, USA \\ ${ }^{2}$ The Ecosystems Center, Marine Biological Laboratory, Woods Hole, Massachusetts 02543, USA
}

\begin{abstract}
Zooplankton fecal pellet contribution to particulate organic carbon (POC) flux over the continental shelf of the western Antarctic Peninsula (WAP) was investigated to better understand the possible effects of changes in zooplankton community structure, due to climate change, on carbon export. Fecal pellets were collected at $170 \mathrm{~m}$ depth in a moored sediment trap from January 2004 to January 2009. Fecal pellet shape and size (i.e., carbon content) were quantified to assess flux of pellets from different zooplankton taxa and compared between seasons and years. Fecal pellet POC constituted the dominant proportion of total POC flux, with summer (November to April) pellet POC flux (67\%) significantly higher than winter (May to October) pellet POC flux $(34 \%)$, while phytodetritus or fecal 'fluff' constituted the remainder. Cylindrical euphausiid pellets contributed to a monthly mean of $72 \%$ of total fecal pellet flux; ovoid copepod and tabular salp pellets contributed significantly less ( 22 and $6 \%$, respectively). Cylindrical and ovoid pellet export was significantly higher in summer, while $48 \%$ of tabular pellet flux occurred in winter. Tabular pellets had the highest carbon content (median $=1.03 \mu \mathrm{gC} \mathrm{pellet}^{-1}$, highest $134.9 \mu \mathrm{gC}$ pellet $^{-1}$ ), followed by cylindrical $\left(0.20 \mu \mathrm{gC}\right.$ pellet $\left.^{-1}\right)$ and ovoid $\left(0.04 \mu \mathrm{gC}\right.$ pellet $\left.{ }^{-1}\right)$ pellets. As krill fecal pellets are the dominant component of particle export in the WAP, we hypothesize that a decrease in krill and increase in salps in the region could alter the export of POC to the deep sea.
\end{abstract}

KEY WORDS: Southern Ocean $\cdot$ Particle flux $\cdot$ Sediment trap $\cdot$ Krill $\cdot$ Salp $\cdot$ Copepod $\cdot$ Climate Resale or republication not permitted without written consent of the publisher

\section{INTRODUCTION}

Zooplankton play a key role in the biological pump through the grazing of phytoplankton and subsequent egestion of dense, rapidly sinking fecal pellets (Urrère \& Knauer 1981, Ducklow et al. 2001, Turner 2002). Although much of the particulate organic carbon (POC) that sinks out of the euphotic zone is attenuated in the mesopelagic zone by bacteria, zooplankton, and micronekton that remineralize sinking POC (Hidaka et al. 2001, Buesseler et al. 2007b, Steinberg et al. 2008), sediment trap studies indicate that a significant proportion of sinking POC that makes it to depth is in the form of zooplankton fecal pellets, indicating the potential to bypass sources of attenuation and resulting in efficient export of POC to the seabed (Buesseler et al. 2007b, Steinberg et al. 2008, Wilson et al. 2008).

The efficiency of fecal pellet export is affected by zooplankton community structure and feeding mode, with sinking rates varying with fecal pellet size, shape, and nutritional content (Fowler \& Small 1972, Wilson et al. 2008, Smith et al. 2011, Atkinson et al. 2012). The dominant Southern Ocean macrozooplankton produce pellets with distinct characteristics. Euphausiids (krill) produce long, cylindrical pellets that can be easily broken as they sink (Fowler \& Small 1972, Atkinson et al. 2012) but have high and 
variable sinking rates of 16 to $1218 \mathrm{~m} \mathrm{~d}^{-1}$ (Turner 2002, McDonnell \& Buesseler 2010, Atkinson et al. 2012). Copepods produce ellipsoid or ovoid pellets. They have round or pointed ends and are encased in a peritrophic membrane that makes the pellets more resistant to bacterial degradation and breakage (Gauld 1957, Yoon et al. 2001, Köster et al. 2011). Copepod fecal pellet sinking rates range from 5 to $220 \mathrm{~m} \mathrm{~d}^{-1}$ (Turner 2002, Møller et al. 2011, Patonai et al. 2011). Salps are indiscriminate feeders that produce very large, fast-sinking ( 42 to $2700 \mathrm{~m} \mathrm{~d}^{-1}$ ) 'fecal flakes' that greatly enhance the efficiency of POC transport to depth (Anderson 1998, Madin \& Deibel 1998, Yoon et al. 2001, Phillips et al. 2009).

Long-term zooplankton time series from a variety of environments indicate that climate is changing zooplankton community structure (Richardson 2008, Steinberg et al. 2012) and that these changes can lead to changes in the efficiency of the biological pump (Steinberg et al. 2012). The western Antarctic Peninsula (WAP) is experiencing one of the most rapid rates of warming on Earth; since 1950, the annual mean air temperature has increased by $2^{\circ} \mathrm{C}$, with average mid-winter temperatures rising by $6^{\circ} \mathrm{C}$ (Vaughan et al. 2003, Ducklow et al. 2012). As a result, the WAP is changing from a cold, dry, polar climate to a warm, humid, maritime climate (Ducklow et al. 2012), with a $40 \%$ decrease in sea ice extent and a $12 \%$ decrease in chl a since 1979 (Stammerjohn et al. 2008, Montes-Hugo et al. 2009, Montes-Hugo et al. 2010). Macrozooplankton abundance and community structure along the WAP also reflect the changes occurring throughout this marine ecosystem due to climate change, through the relative abundance of 2 major grazers: krill Euphausia superba and salps Salpa thompsoni (Quetin \& Ross 2001, Pakhomov et al. 2002, Atkinson et al. 2004, Ross et al. 2008). Antarctic krill abundance is dependent on both summer food availability and winter sea ice necessary for larval recruitment and survival, while salps can survive in regions of lower productivity and are not dependent on sea ice (Quetin \& Ross 2001, Atkinson et al. 2004). Data from net tows in the Southern Ocean from 1926 to 2003 show a significant decrease in krill since 1976 in the WAP region, while salp densities have increased throughout the entire Southern Ocean (Pakhomov et al. 2002, Atkinson et al. 2004). Since zooplankton community structure directly affects carbon export through fecal pellet production, changes in the zooplankton community could potentially impact biogeochemical cycling off the WAP (Ducklow 2008, Smith et al. 2011, Steinberg et al. 2012).
We examined the composition of sinking particles collected from January 2004 to January 2009 in a time-series sediment trap located on the WAP continental shelf (Ducklow 2008, Ducklow et al. 2012) to investigate the role of zooplankton in affecting particle export. Zooplankton fecal pellet abundance, shape, size, and carbon content were quantified to assess the contribution of pellets from different zooplankton taxa to total POC flux and compared between seasons and years. The continental shelf of the WAP experiences a high seasonal vertical particle flux, 10000 times greater in summer than in winter (Ducklow et al. 2008), that exports carbon to the deep sea (Karl et al. 1991b) and is an important mechanism of $\mathrm{CO}_{2}$ storage in the ocean carbon system (Ducklow et al. 2008). Thus, our results are used to predict how changes in zooplankton community composition along the WAP may lead to changes in the efficiency of the biological pump.

\section{MATERIALS AND METHODS}

\section{Sediment trap deployment and retrieval}

Samples were collected in a bottom-moored sediment trap (PARFLUX Mark 78H 21-sample trap, McLane Research Labs) deployed annually since 1992 on the continental shelf located $\sim 130 \mathrm{~km}$ west of the Antarctic Peninsula (64 $30^{\prime} \mathrm{S}, 66^{\circ} 00^{\prime} \mathrm{W}$ ) (Fig. 1). The location where the sediment trap is deployed is seasonally covered with sea ice $112 \pm 9$ days (mean \pm SD) per year (data from 1979 to $2011, \mathrm{n}=32$ ), with a mean advance in early to mid-July (Day of Year 190 \pm 5 ) and mean retreat in early November (Day of Year $310 \pm 6$; Ducklow et al. 2012, S. Stammerjohn pers. comm.).

We analyzed sediment trap samples from the most recent trap recoveries, January 2005 to January 2009. These trap deployments and recoveries were performed aboard the ARSV 'Laurence M. Gould' in January of each year on the Palmer Antarctica LongTerm Ecological Research (LTER) annual cruises. The bottom depth at the deployment site is $350 \mathrm{~m}$, with the trap suspended at a depth of $170 \mathrm{~m}$. The trap contains 21 sample bottles that autonomously collect samples throughout the year at intervals varying from 7 to $30 \mathrm{~d}$, corresponding with anticipated seasonal flux (Ducklow et al. 2008). During peak flux in the austral summer (November to April), the sample carousel rotates bottles weekly, and in the austral winter (May to October), intervals are monthly. There were gaps of $5 \mathrm{~d}$ between mooring recovery 


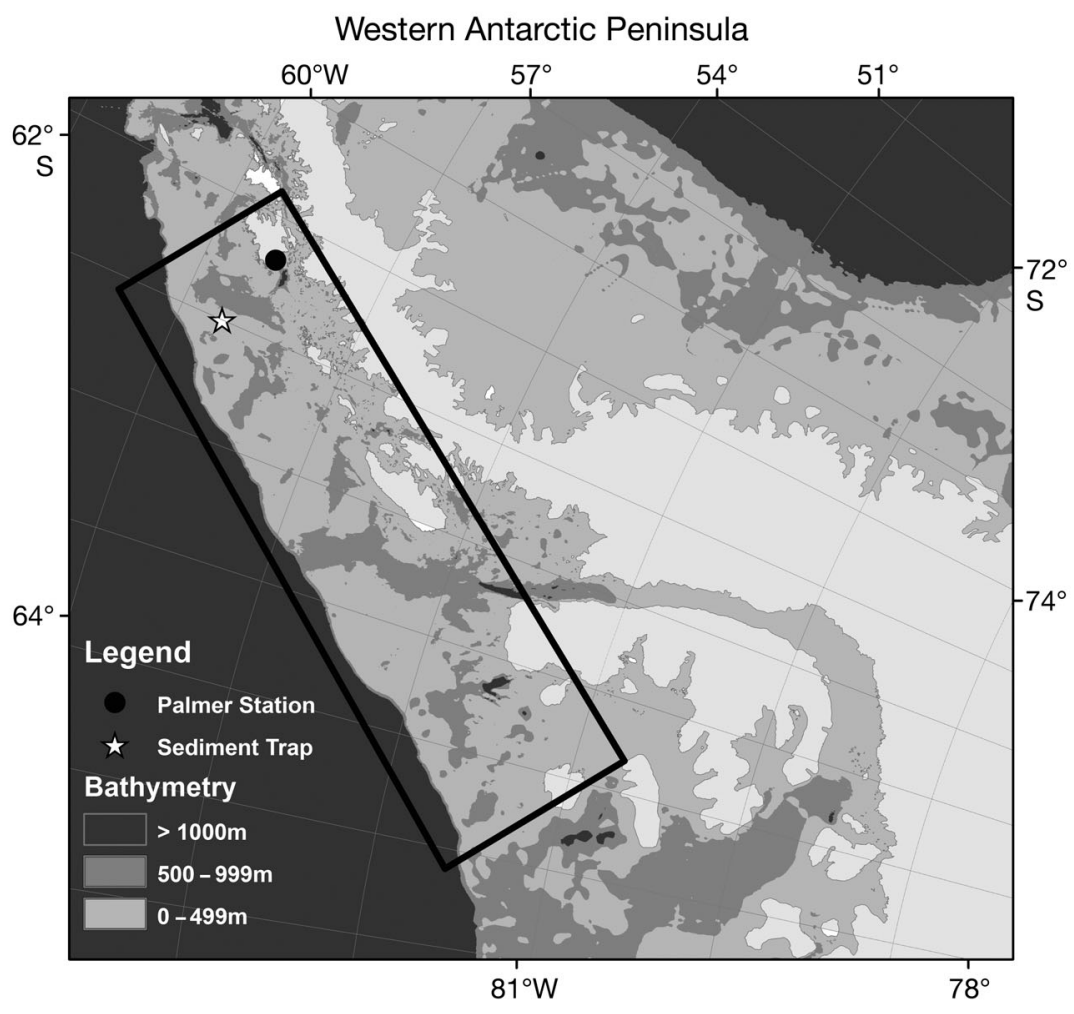

Fig. 1. Palmer Long-Term Ecological Research (LTER) study region along the western Antarctic Peninsula (WAP) with sampling area (black rectangle) and bathymetry. it: location of long-term sediment trap mooring $\left(64^{\circ} 30^{\prime} \mathrm{S}, 66^{\circ} 00^{\prime} \mathrm{W}\right)$. •: location of Palmer Station (US Antarctic Program) and nitrogen on a Control Equipment Corporation (CEC) 240-XA Elemental Analyzer (Leeman Labs) (Karl et al. 1991a, Ducklow et al. 2008), with the other half saved for pellet analysis.

\section{Fecal pellet analysis}

The fecal pellet analysis protocol was adapted from Wilson et al. (2008). Preserved sediment trap samples were analyzed using an Olympus SZX12 dissecting scope at $25 \times$ magnification with an Olympus DP71 digital camera under bright-field and dark-field illumination. Samples too dense to analyze were split using a plankton splitter until individual pellets were readily visible. The range of splits analyzed was $1 / 2$ to 1/512 of the total trap sample. The subsample was poured into a petri dish with a grid containing pre-measured squares. Squares were randomly chosen, and pellets within the squares were photographed until at least 100 pellets of each type were photographed (with the occasional exception of samples with too few pellets overall). Larger, rare pellets were photographed and deployment. The 21 plastic sample collection bottles on the trap were prepared before deployment with a Milli-Q deionized water (DI) rinse and filled with a $7.5 \mathrm{~g} \mathrm{NaCl}^{-1}$ solution and $2 \%$ borate-buffered formalin in filtered seawater (34 ppt), with a final concentration of 41 ppt (Ducklow et al. 2008).

\section{Sample processing}

After retrieval, trap samples were gently rinsed through a $1000 \mu \mathrm{m}$ Nitex ${ }^{\complement}$ mesh to remove large swimmers, with swimmer-free material replaced in the sample, sealed, and stored at $5^{\circ} \mathrm{C}$ until processing in the laboratory. Starting with the January 2008 to January 2009 series, samples were pre-screened, and any remaining swimmers and molts were individually removed by hand. Zooplankton remains and molts were preserved in $2 \%$ formaldehyde. Swimmer-free trap samples were split using a plankton splitter; half (except for cups with insufficient sediment) were treated with dilute $\mathrm{HCl}$ to remove inorganic carbon, then analyzed for total organic carbon from the entire sample prior to the subsample split. Pellet volumes in splits were later extrapolated to the whole sample to account for all pellets by taking into account the area of the dish and number of squares counted.

Digital images were analyzed with Image-Pro Plus ${ }^{\circledR}$ software measuring recognizable pellets for quantify size; constant camera settings and light conditions were used. In addition to analysis using Image-Pro Plus ${ }^{\circledR}$, pellets were visually categorized by general shape (Fig. 2). Fecal pellet production experiments in the field gave a general idea of the types of zooplankton producing these pellet shapes: copepods (ovoid), krill (cylindrical), and salps (tabular) (Urrère \& Knauer 1981, Wilson et al. 2008, Steinberg et al. 2009). We assumed tabular pellets were from salps, although some could be from small fish (Saba \& Steinberg 2012). The volume of each pellet was calculated using digital image measurements of pellet length and width analyzed using Image-Pro corresponding ovoid, cylindrical, and tabular shapes. size as in Wilson et al. (2008). Images were used to Plus ${ }^{\circledR}$ and converted to volume using formulas for 

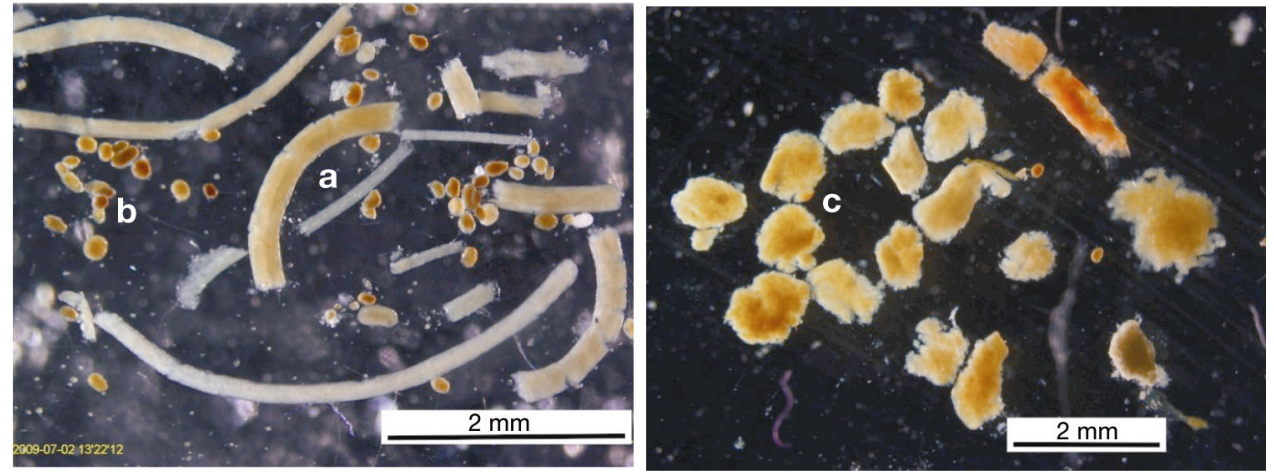

Fig. 2. Example fecal pellet types from different taxa. Left panel: long, cylindrical pellets from krill (a); small, ovoid pellets from copepods (b). Right panel: large, tabular-shaped pellets from salps (c)

The extent to which pellets were degraded (e.g., lacking peritrophic membrane or broken) was noted. The presence of particles not recognizable as pellets was recorded, including phytodetritus (phytoplankton detritus, determined microscopically by the presence of diatom tests using an Olympus BX53 compound scope at 100 to $600 \times$ magnification), fecal 'fluff', and foraminifera.

\section{Pellet volume to carbon conversion and pellet $\mathrm{C}$ flux}

Pellet volumes were converted to carbon by $\mathrm{CHN}$ analysis of groups of pre-measured pellets of each type for volume and were verified from correlation of trap POC flux and pellet volume in trap samples containing exclusively pellets.

Ovoid, cylindrical, and tabular pellets randomly selected from 2008 to 2009 sediment trap samples (including a range of loose to tightly packaged pellets from summer and winter) were removed and measured using image analysis as described in 'Fecal pellet analysis'. The pellets were then rinsed onto combusted $25 \mathrm{~mm}$ GF/F filters using $5 \mathrm{ml}$ of DI water. Groups of ovoid pellets ( $\mathrm{n}=4$, mean number of pellets per filter $=259)$, cylindrical pellets $(\mathrm{n}=8$, mean number of pellets per filter $=35)$, tabular pellets $(n=$ 3 , mean number of pellets per filter $=2$ ), and blanks ( $\mathrm{n}=4$, with $5 \mathrm{ml}$ from pellet sample water rinsed with $5 \mathrm{ml}$ DI water) were analyzed.

Samples and blank filters were placed in glassware and capped with aluminum foil (all materials used in analysis were pre-combusted at $525^{\circ} \mathrm{C}$ for $2 \mathrm{~h}$ ). Filters were dried at $60^{\circ} \mathrm{C}$, placed in a desiccator with a small beaker containing $\sim 20 \mathrm{ml}$ of concentrated $\mathrm{HCl}$ for $16 \mathrm{~h}$ to remove inorganic carbonates, and returned to the oven until completely dry. The acidified filters were packed into tin capsules and processed using either a Costech ECS 4010 CHNSO analyzer or a Thermo Scientific FlashEA 1112 Organic Elemental Analyzer for flash combustion with acetanilide or atropine as the authenticated standard.

Volume of the pellets on each filter was summed and carbon:volume ratio calculated for each with mean blank adjustment: $\left(\mathrm{mgC}-\mathrm{mgC}_{\text {blanks }}\right) /$ volume $\left(\mathrm{mm}^{-3}\right)$. The mean carbon:volume ratio from all filters (all pellet types) yielded a carbon conversion factor of $0.02 \mathrm{mgC} \mathrm{mm}$. Carbon:volume ratio (mean $\pm \mathrm{SD}$ ) was $0.016 \pm 0.002,0.041 \pm 0.019$, and $0.021 \pm 0.021 \mathrm{mgC} \mathrm{mm}^{-3}$ for cylindrical, ovoid, and tabular pellets, respectively.

These values were compared to a regression of total pellet volume $\left(\mathrm{mm}^{3}\right)$, from samples observed to be exclusively comprised of pellets, vs. total POC flux $\left(\mathrm{mgC} \mathrm{m}^{-2} \mathrm{~d}^{-1}\right)$, obtained from CHN analysis of the same sample $\left(y=56.75 x-152.81, r^{2}=0.78\right.$, $\mathrm{n}=55$ ). The inverse of the slope of the regression of fecal pellet volume vs. total POC flux (1/56.75) yielded a conversion factor of $0.018 \mathrm{mgC} \mathrm{mm}^{-3}$.

Based on these 2 methods, we chose a carbon:volume conversion of $0.02 \mathrm{mgC} \mathrm{mm}^{-3}$ for cylindrical and tabular pellets, and of $0.04 \mathrm{mgC} \mathrm{mm}^{-3}$ for ovoid ones, which were more compact than the other pellet types. Total pellet $\mathrm{C}(\mathrm{mg})$ in each sample was converted to pellet carbon flux $\left(\mathrm{mgC} \mathrm{m}^{-2} \mathrm{~d}^{-1}\right)$ by dividing by the known area of the trap $\left(0.5 \mathrm{~m}^{2}\right)$ and individual sample collection interval (ranging from 7 to $31 \mathrm{~d}$ ).

\section{Data analysis}

The total carbon flux from pellets for each sample was compared to total POC flux and, for some analyses, combined and averaged by month or season (summer $=$ November to April, winter $=$ May to October). Since a sampling interval may have been less than a month or may have spanned several months, a 
weighted monthly flux $\left(F_{\mathrm{m}}, \mathrm{mgC} \mathrm{m} \mathrm{m}^{-2} \mathrm{~d}^{-1}\right)$ was calculated as:

$$
F_{\mathrm{m}}=\sum_{i=1}^{n}\left(\mathrm{~F}_{i} / \mathrm{D}_{i}\right) / \mathrm{D}_{m}
$$

where $n=$ number of sampling intervals that included the month $m, F_{i}=$ flux for interval $i, D_{i}=$ number of days in month $m$ during interval $i$, and $D_{m}=$ total number of days in month $m$.

Sample bottles from June and July 2005 and from June and September to December 2007 were not analyzed for pellets, as samples were either not preserved properly or did not contain enough fecal material for a quantitative analysis. In addition, the single trap sample from July to August 2007 did not contain enough material for total POC analysis. The calculated proportion of total POC that was fecal pellets occasionally yielded values $>100 \%$, likely due to splitting error (see Results and Discussion); thus, any value $>100 \%$ was replaced with a value of $100 \%$ for any subsequent calculations. For size (i.e., carbon content) frequency analyses, pellets of different shapes for all samples were binned in 10 size classes and samples of each pellet shape normalized to 1000 pellets: [(number of pellets in a size class/total number of pellets of that shape) $\times 1000$ ]. A WilcoxonMann-Whitney test and univariate ANOVA were used to calculate differences between pellet carbon flux for seasons, pellet shapes, and years.

\section{RESULTS}

\section{Fecal pellet carbon flux}

There is seasonality in fecal pellet POC flux that mirrors the pattern in total POC flux (Fig. 3; Table 1). Monthly fecal pellet POC flux (mean $\pm \mathrm{SE}$ ) was significantly higher in summer (November to April: $12.0 \pm 4.6 \mathrm{mgC} \mathrm{m}^{-2} \mathrm{~d}^{-1}, \mathrm{n}=72$ ) than in winter (May to October: $0.21 \pm 0.07 \mathrm{mgC} \mathrm{m}^{-2} \mathrm{~d}^{-1}, \mathrm{n}=19$ ) (Wilcoxon-

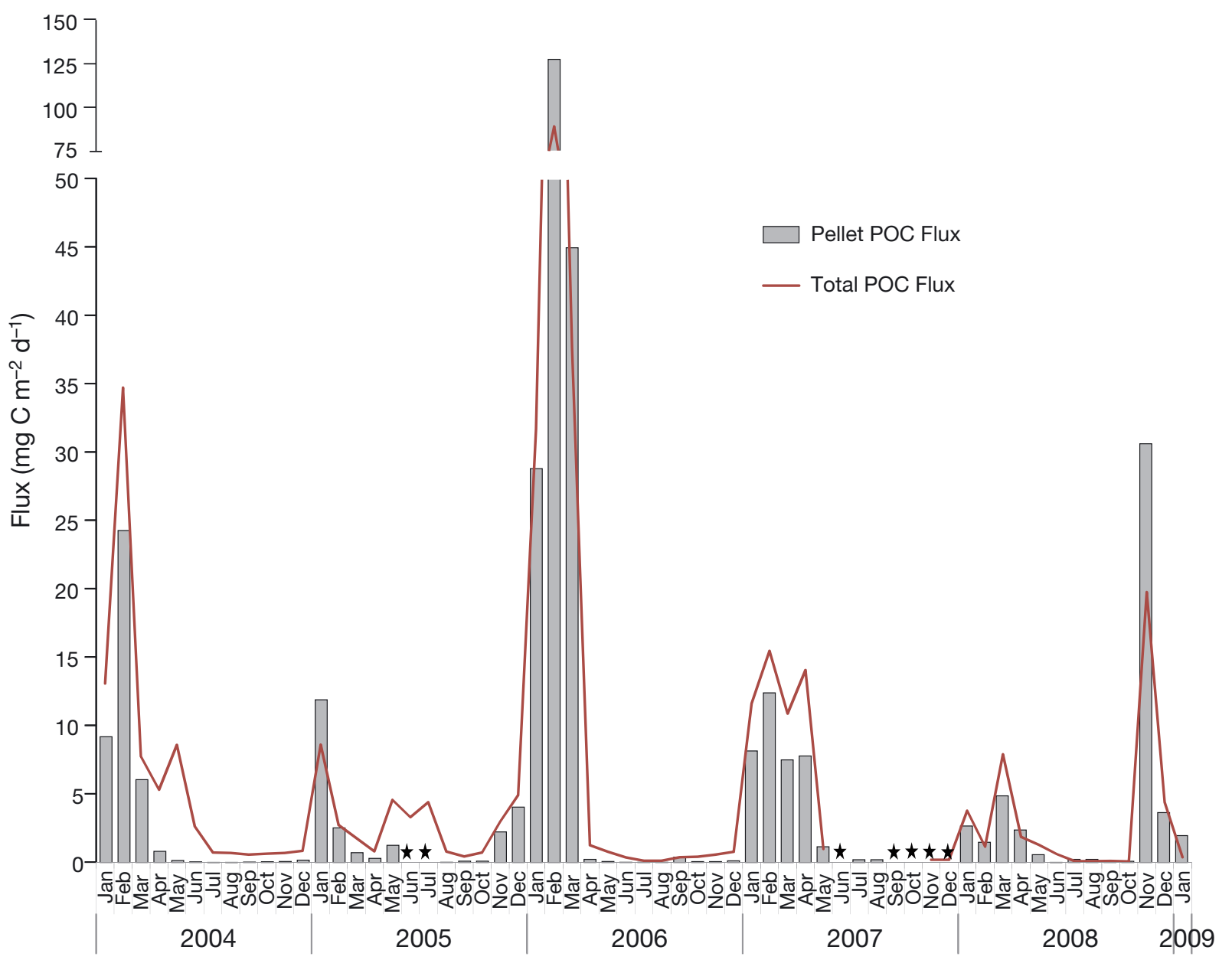

Fig. 3. Fecal pellet particulate organic carbon (POC) flux for each month from January 2004 to January 2009. Pellet flux in summer months is the weighted average ( $\mathrm{n}=2$ to 5 ; see Methods). Red line: total POC for each month. $\star$ : samples not analyzed for pellets due to small amount of material in trap samples 
Table 1. Fecal pellet flux and proportion of total particulate organic carbon (POC) flux for 3 pellet types (cylindrical, ovoid, tabular) and total pellets. Means $\pm \mathrm{SE}$ are calculated for the entire time-series (all months) as well as for summer and winter. $\mathrm{n}=$ number of months

\begin{tabular}{|c|c|c|c|c|c|c|c|c|}
\hline & \multicolumn{4}{|c|}{ Flux $\left(\mathrm{mgC} \mathrm{m}^{-2} \mathrm{~d}^{-1}\right)$} & \multirow{2}{*}{$\begin{array}{c}\text { Total fecal } \\
\text { pellet POC (\%) } \\
\text { All }\end{array}$} & \multicolumn{3}{|c|}{$\ldots$ POC flux $(\%)$} \\
\hline & All & Summer & Winter & Max. & & Summer & Winter & Max. \\
\hline Cylindrical & $6.17 \pm 2.53$ & $11.36 \pm 4.53$ & $0.14 \pm 0.05$ & 125.46 (Feb 2006) & $72 \pm 4$ & $82 \pm 4$ & $61 \pm 6$ & 100 \\
\hline Ovoid & $0.35 \pm 0.09$ & $0.61 \pm 0.14$ & $0.04 \pm 0.02$ & 3.06 (Apr 2007) & $22 \pm 4$ & $17 \pm 4$ & $27 \pm 6$ & 99 \\
\hline Tabular & $0.02 \pm 0.01$ & $0.02 \pm<0.01$ & $0.02 \pm 0.01$ & 0.22 (May 2005) & $6 \pm 2$ & $0.8 \pm 0.3$ & $12 \pm 4$ & 66 \\
\hline Total & $6.53 \pm 2.58$ & $11.99 \pm 4.59$ & $0.21 \pm 0.07$ & 127.38 (Feb 2006) & $53 \pm 6$ & $67 \pm 6$ & $34 \pm 9$ & 100 \\
\hline $\mathrm{n}$ & 54 & 29 & 25 & 54 & 54 & 29 & 23 & 54 \\
\hline
\end{tabular}

Mann-Whitney test, $\mathrm{p}<0.001)$. Peak fecal pellet POC flux usually occurred in February, as in 2004, 2006, and $2007\left(24.3,127.4\right.$, and $12.4 \mathrm{mgC} \mathrm{m}^{-2} \mathrm{~d}^{-1}$, respectively), but peak fecal pellet flux also occurred in January in 2005 (11.9 $\left.\mathrm{mgC} \mathrm{m}^{-2} \mathrm{~d}^{-1}\right)$ and in November in 2008 (30.7 $\mathrm{mgC} \mathrm{m}^{-2} \mathrm{~d}^{-1}$ ). Seasonal mean fecal pellet flux values were not significantly different between years for either summer or winter fluxes (univariate ANOVA; Summer and Year: $F=1.193$, $\mathrm{df}=4, \mathrm{p}=0.323$; Winter and Year: $F=1.970, \mathrm{df}=4$, $\mathrm{p}=0.145)$.

Fecal pellet POC was a large proportion of the total POC flux, with recognizable pellets on average equivalent to $53 \pm 6 \%$ of the total POC flux for the whole time series (Fig. 4; Table 1). The proportion of total sinking POC that was fecal pellets (mean $\pm \mathrm{SE}$ )

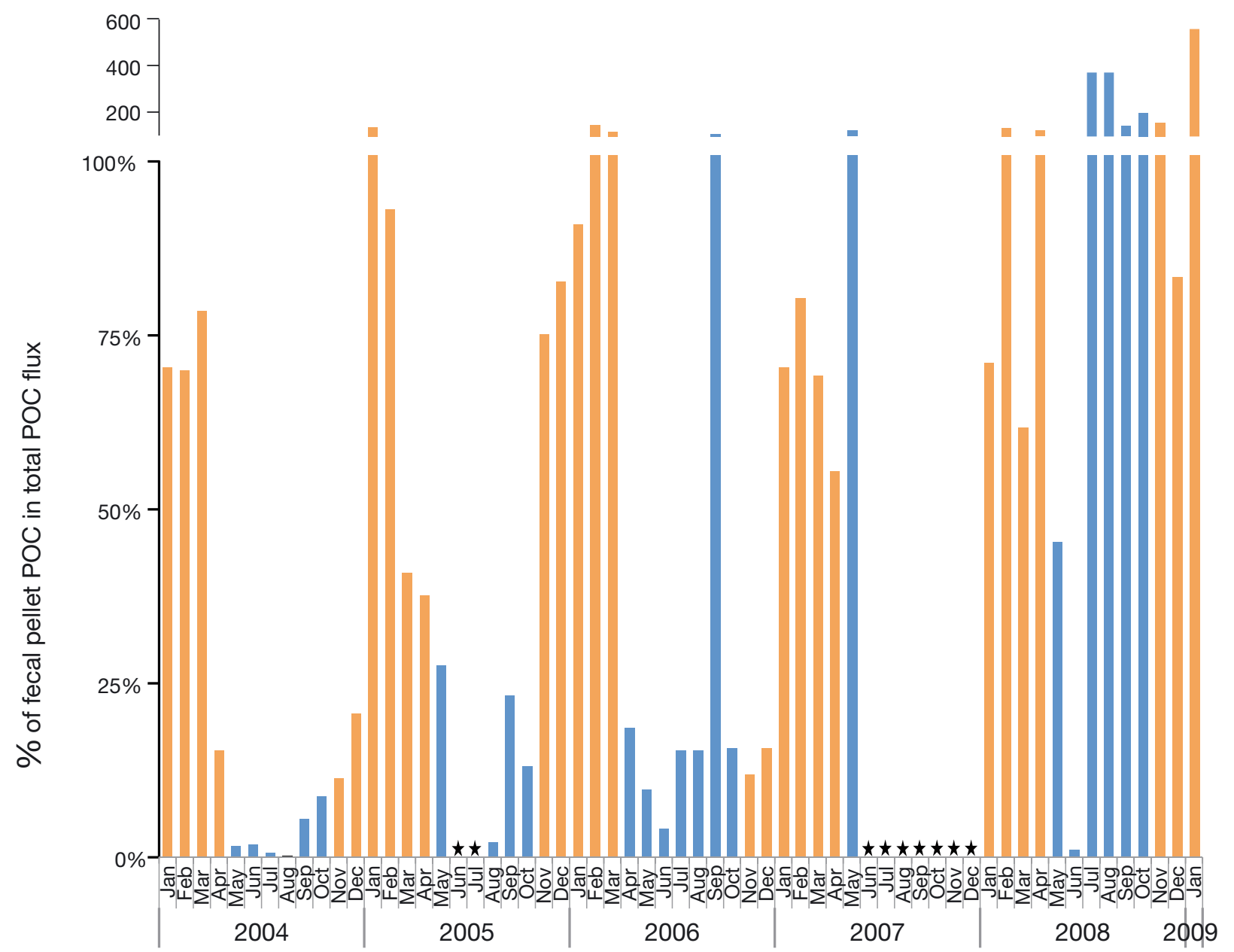

Fig. 4. Proportion of total particulate organic carbon (POC) flux that is fecal pellets. $\star$ : samples not analyzed for pellets due to small amount of material in trap samples. Orange bars $=$ summer, blue bars $=$ winter. (Note: any sample with $>100 \%$ fecal pellets is treated as $100 \%$ in calculations; see 'Materials and methods') 
was significantly higher in summer $(67 \pm 6 \%$, range $=$ 11 to $100 \%, \mathrm{n}=29)$ than in winter $(34 \pm 9 \%$, range $=$ $<1$ to $100 \%, \mathrm{n}=23$ ) (Wilcoxon-Mann-Whitney test, $\mathrm{p}<0.001)$. As Fig. 4 indicates, several samples had higher calculated fecal POC than total POC flux, likely due to errors in the sample splitting procedure or natural variability in pellet carbon content (see Discussion); the above averages are thus calculated replacing any value $>100 \%$ with a value of $100 \%$.

In addition to fecal pellets, other particulate matter such as phytodetritus and fecal fluff (decomposed phytoplankton and degraded pellets, respectively) occurred regularly in trap samples and changed with season (Fig. 5). From qualitative visual observations, phytodetritus or fecal fluff was obvious in $31 \%$ of summer samples analyzed $(\mathrm{n}=72)$ and in $74 \%$ of winter samples analyzed $(\mathrm{n}=19)$. This seasonal trend in particle type is illustrated in Fig. 5: in summer, high numbers of krill pellets, fecal fluff associated with pellets, and little phytodetritus; in late summer, decreasing but higher variety of pellets and some non-pellet material; and in winter, few pellets (including tabular) and increased phytodetritus (phytodetritus in winter, however, was equal to only a small proportion of the flux in summer that is primarily pellets). Early summer samples were similar to late summer samples.

\section{Fecal pellet type}

Flux of the 3 fecal pellet shapes varied significantly, with considerably higher flux of cylindrical krill fecal pellets than other types (monthly mean flux over whole time series $\pm \mathrm{SE}$ : cylindrical $=6.2 \pm 2.5$, ovoid $=0.4 \pm 0.1$, tabular $=0.02 \pm 0.01 \mathrm{mgC} \mathrm{m}^{-2} \mathrm{~d}^{-1}$, a Summer

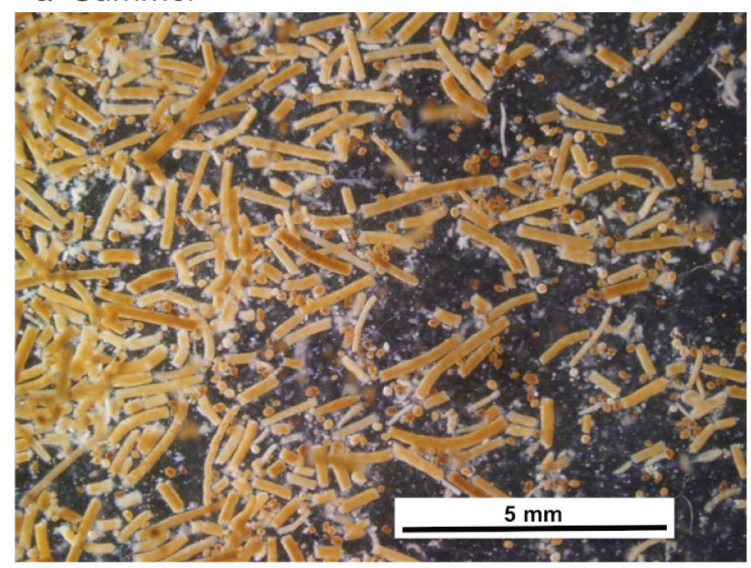

c Winter

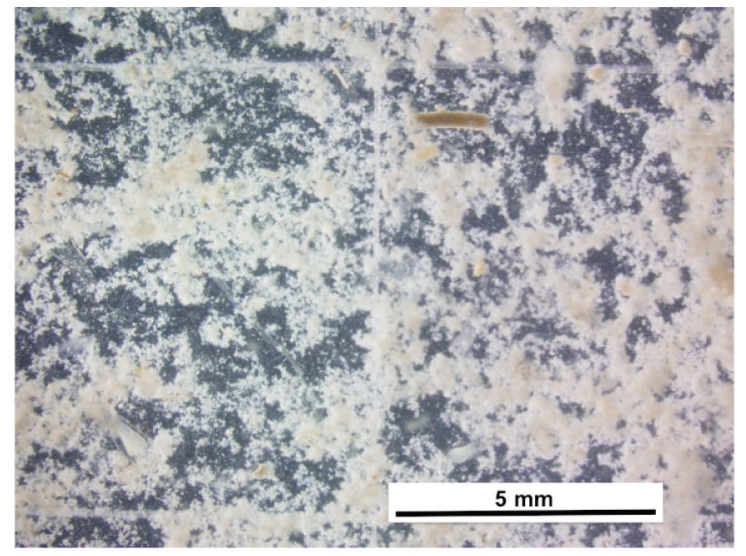

b Late summer

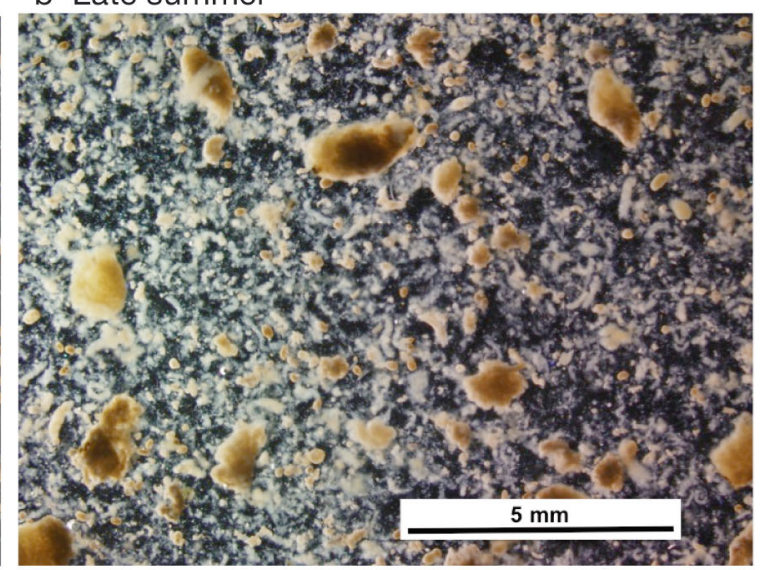

d Early summer

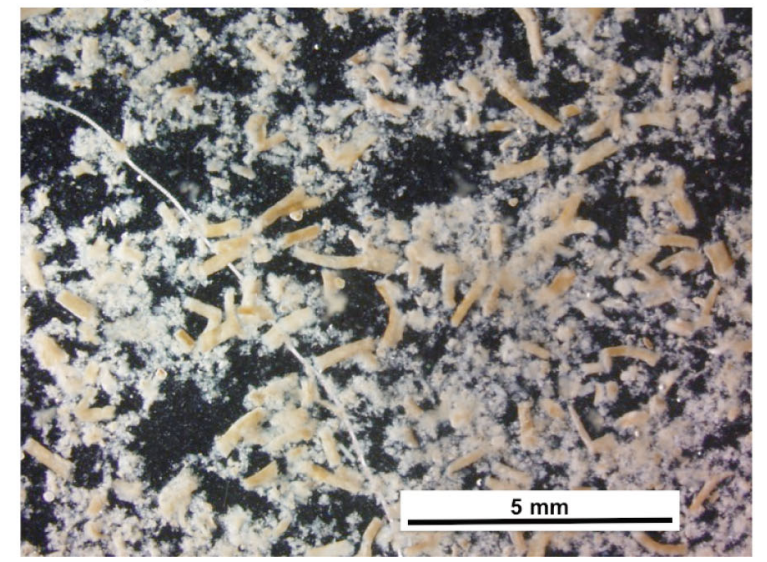

Fig. 5. Representative images depicting seasonal difference in pellet type, density, degradation, and amount of non-pellet material (phytodetritus or fecal 'fluff'). (a) Summer (January 2005): mostly krill pellets with little non-pellet material. (b) Late summer (April 2005): fecal fluff associated with loose and tabular pellets; phytodetritus also present. (c) Winter (June 2006): dominated by phytodetritus with few pellets. (d) Early summer (November 2005): some phytodetritus with recognizable krill pellets and fecal fluff from broken or loose pellets. Sample splits: $(a, b, d) 3 / 4 ;$ (c) $1 / 2$ 
$\mathrm{n}=54$; Wilcoxon-Mann-Whitney test, $\mathrm{p}<0.001$ ) (Table 1). Also, ovoid pellets had a significantly higher flux than tabular pellets $(p<0.001)$. Mean carbon flux of any pellet type did not vary significantly among years (univariate ANOVA: Cylindrical $\times$ Year $\mathrm{p}=0.374$, Ovoid $\times$ Year $\mathrm{p}=0.781$, Tabular $\times$ Year $\mathrm{p}=$ $0.125, \mathrm{df}=4)$.

The seasonality of flux of fecal pellets of different types is shown as a monthly composite in Fig. 6 . Cylindrical pellet flux peaks in February (32.7 \pm $23.5 \mathrm{mgC} \mathrm{m}^{-2} \mathrm{~d}^{-1}$ ) and is more than 10 times higher in summer months than flux of ovoid and tabular pellets combined (Fig. 6a). Peak heights in the monthly composite of cylindrical pellet flux also correspond to the total pellet POC flux (Figs. $3 \& 4$ ).

The highest cylindrical krill pellet flux for the time series was $125.5 \mathrm{mgCm}^{-2} \mathrm{~d}^{-1}$ (February 2006), and cylindrical pellets (means \pm SE) constituted $72 \pm 4 \%$ of the total pellet flux, with higher flux during summer each year $\left(11.4 \pm 4.5 \mathrm{mgCm}^{-2} \mathrm{~d}^{-1}\right.$ in summer and $0.14 \pm 0.05 \mathrm{mgC} \mathrm{m}^{-2} \mathrm{~d}^{-1}$ in winter; Table 1). Flux in some months was comprised almost entirely of cylin-

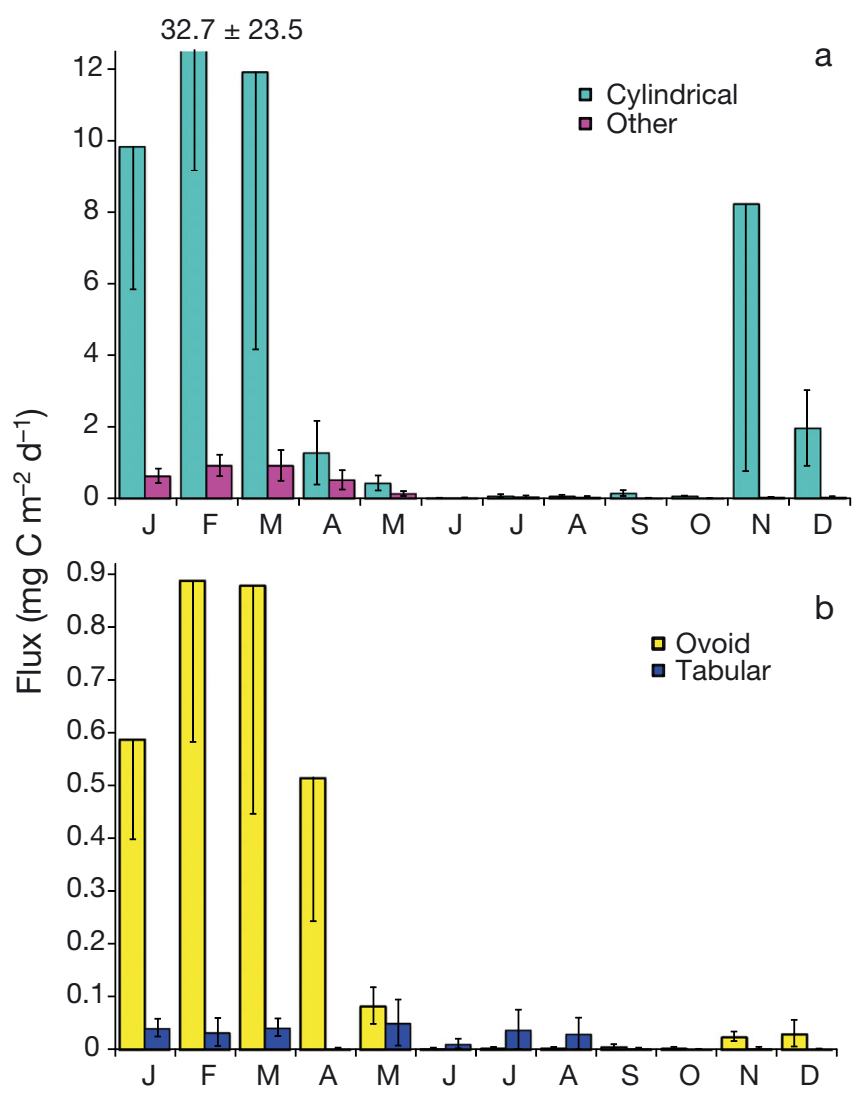

Fig. 6. Monthly composite of fecal pellet flux by pellet type. Mean \pm SE for each month from January 2004 to January 2009. (a) Cylindrical and other (= ovoid and tabular combined) pellets, (b) ovoid and tabular pellets drical pellets (up to $99.9 \%$ ). However, flux of ovoid and tabular pellets combined (and not monthly averaged) was higher than cylindrical krill pellets in some winter months for all years except 2007. The highest was April 2005, when flux of non-krill pellets constituted $96 \%$ of total pellet flux and was $0.3 \mathrm{mgC} \mathrm{m}^{-2}$ $\mathrm{d}^{-1}, 26$ times higher than krill pellet flux in that month.

Ovoid pellets (mean $\pm \mathrm{SE}$ ) constituted $22 \pm 4 \%$ of total pellet flux (mean of monthly means; Table 1). Their flux ranged from $<0.01 \mathrm{mgC} \mathrm{m}^{-2} \mathrm{~d}^{-1}$ to $3.1 \mathrm{mgC}$ $\mathrm{m}^{-2} \mathrm{~d}^{-1}$ (April 2007), with higher flux during summer each year: $0.6 \pm 0.1 \mathrm{mgC} \mathrm{m}^{-2} \mathrm{~d}^{-1}$ in summer and $0.04 \pm 0.02 \mathrm{mgC} \mathrm{m}^{-2} \mathrm{~d}^{-1}$ in winter. There was a significant positive correlation between monthly flux of cylindrical and ovoid pellet types in a $\log (x+1)$ transformation regression to achieve heteroskedacity $(y=$ $2.33 x+0.16, \mathrm{r}=0.671, \mathrm{n}=54, \mathrm{p}<0.001)$. Furthermore, the monthly composite peak for both cylindrical krill pellets and ovoid pellets was in February (cylindrical $=32.7 \pm 23.5 \mathrm{mgC} \mathrm{m}^{-2} \mathrm{~d}^{-1}$, ovoid $=0.9 \pm$ $0.3 \mathrm{mgC} \mathrm{m}^{-2} \mathrm{~d}^{-1}$; Fig. 6b).

Tabular pellets contributed the least to pellet carbon flux, constituting $6 \pm 2 \%$ of total pellet flux (mean of monthly means) and a maximum monthly flux of $0.2 \mathrm{mgC} \mathrm{m}^{-2} \mathrm{~d}^{-1}$ in May 2005 (Table 1). While cylindrical and ovoid pellet flux was higher in summer, tabular pellet flux was similar for both summer and winter (summer: $0.02 \pm<0.01 \mathrm{mgC} \mathrm{m}^{-2} \mathrm{~d}^{-1}$, winter: $\left.0.02 \pm 0.01 \mathrm{mgC} \mathrm{m}^{-2} \mathrm{~d}^{-1}\right)$. In the monthly composite, the tabular pellet flux is $<0.1 \mathrm{mgC} \mathrm{m}^{-2} \mathrm{~d}^{-1}$ for all months, with no defined peak month (Fig. 6b).

\section{Fecal pellet size (carbon content)}

The largest pellets in the trap were tabular (mostly salp) $\left(\right.$ mean $=3.62 \mu \mathrm{gC}$ pellet $^{-1}$, median $=1.03 \mu \mathrm{gC}$ pellet $^{-1}$; Table 2), of which $99 \%$ were $>0.1 \mu \mathrm{gC}$ pellet $^{-1}$ (Fig. 7 ) and up to 100 times larger than other pellet types. Cylindrical (mostly krill) pellet carbon content was more normally distributed, with the

Table 2. Carbon content (median, mean, maximum) for 3 pellet types (cylindrical, ovoid, tabular)

\begin{tabular}{|lrccr|}
\hline & \multirow{4}{*}{$\mathrm{n}$} & \multicolumn{3}{c|}{ Carbon content $\left(\mu \mathrm{gC} \mathrm{pellet}^{-1}\right)$} \\
& & Median & Mean & Max. \\
\hline Cylindrical & 8019 & 0.20 & 0.39 & 16.68 \\
Ovoid & 4634 & 0.04 & 0.08 & 3.88 \\
Tabular & 473 & 1.03 & 3.62 & 134.87 \\
All & 13126 & 0.10 & 0.40 & 134.87 \\
\hline
\end{tabular}




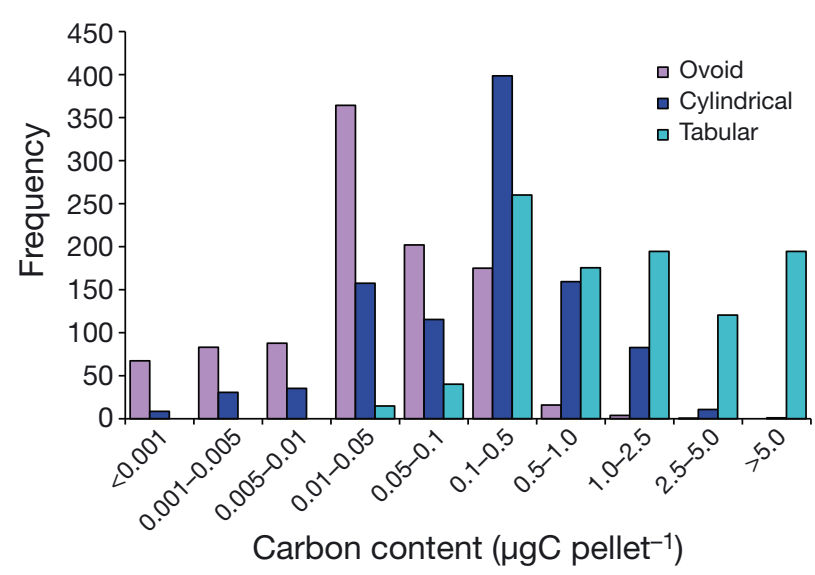

Fig. 7. Size class (carbon content, $\mu \mathrm{gC}$ pellet $^{-1}$ ) frequency distribution for 3 pellet types (ovoid, cylindrical, tabular) from entire time series. Pellet counts were normalized to 1000 pellets for each pellet type [(number of pellets in a size class/total number of pellets) $\times 1000$ ]

highest frequency of pellets (40\%) in the 0.1 to $0.5 \mu \mathrm{g}$ C pellet ${ }^{-1}$ class, a mean pellet C of $0.39 \mu \mathrm{gC} \mathrm{pellet}^{-1}$, and median pellet $\mathrm{C}$ of $0.20 \mathrm{\mu gC}$ pellet $^{-1}$ (Table 2). Ovoid pellets were the smallest (mean $=0.08 \mu \mathrm{gC}$ pellet $^{-1}$, median $=0.04 \mu \mathrm{gC}$ pellet $^{-1}$; Table 2), with $80 \%$ of pellets $<0.1 \mu \mathrm{gC}$ pellet $^{-1}$ and the highest frequency of pellets (36\%) in the 0.01 to $0.05 \mu \mathrm{gC}$ pellet $^{-1}$ class (Fig. 7).

\section{DISCUSSION}

\section{Seasonality of flux and contribution of fecal pellets}

The polar regions of the oceans are characterized by high seasonal variability in flux due to seasonal sea ice coverage (Ducklow et al. 2008), with a significant annual peak in sedimentation in the Antarctic marginal ice zone following ice retreat (Wefer et al. 1988, Honjo et al. 2000, Ducklow et al. 2008, Smith et al. 2011). The seasonal variability in total POC flux, also previously observed in the Palmer LTER sediment trap time series (Ducklow et al. 2008), is mirrored in the flux of fecal pellet POC, with mean fecal pellet flux in summer on average 60 times higher than winter pellet flux. The proportion of total flux that was fecal pellets was variable throughout the time series but with a significant seasonal difference. Fecal pellets constituted a higher proportion of total POC flux in summer (67\%) than in winter $(34 \%)$. This is consistent with the fecal pellet contribution to flux in polar regions, where spring phytoplankton blooms lead to increased food availability to support a high zooplankton biomass that mediates export in summer (Wassmann 1997). The fecal pellet contribution to total POC flux off the WAP is higher than or similar to other high-latitude regions. In the Ross Sea, Antarctica, total POC flux maxima also occurred in January and February, with fecal pellets contributing 6 to $21 \%$ (mean 2.4 to $28.4 \mathrm{mgC} \mathrm{m}^{-2} \mathrm{~d}^{-1}$ ) of total POC flux, using a carbon:volume conversion of $0.016 \mathrm{mgC}$ $\mathrm{mm}^{-3}$ (Smith et al. 2011). In the Barents Sea in the Arctic, fecal pellet flux contributed to 9 to $46 \%$ of POC flux in spring (Wexels Riser et al. 2008). In comparison, fecal pellet composition in mid-latitude oligotrophic and subpolar mesotrophic regions of the North Pacific Ocean in summer was lower, 14 to $35 \%$ and 3 to $29 \%$, respectively, of total POC flux (Wilson et al. 2008; employing the same fecal pellet analysis methods as in the present study). Similarly, pellet contribution to POC flux in the oligotrophic North Atlantic subtropical gyre averaged $30 \%$ (Huskin et al. 2004) and $<25 \%$ in the Mediterranean Sea (Carroll et al. 1998, Wassmann et al. 2000).

Our calculated fecal pellet contribution to total POC is dependent upon the carbon:volume conversion applied. Our conversion factors of $0.02 \mathrm{mgC}$ $\mathrm{mm}^{-3}$ for krill and salp pellets and $0.04 \mathrm{mgC} \mathrm{mm}^{-3}$ for copepod pellets (calculated from CHN analysis of pellets pre-measured for volume and verified by correlation of fecal pellet volume with measured total POC in samples exclusively containing pellets, see 'Materials and methods'), fall at the low end of the range of carbon: volume conversions in the literature of 0.01 to $0.15 \mathrm{mgC} \mathrm{mm}^{-3}$ but are similar to values in other polar studies (Urrère \& Knauer 1981, González 1992, Wassmann et al. 2000, Wexels Riser et al. 2008, Wilson et al. 2008, Smith et al. 2011). The krill and salp carbon conversion is consistent with a krill-dominated Antarctic zooplankton community, as krill may produce 'looser', lower carbon:volume pellets than copepods (Gauld 1957, Atkinson et al. 2012). Thus, we used a different carbon:volume conversion for copepod pellets, as they produce small, compact pellets enclosed in a peritrophic membrane.

The range in summer mean $C$ flux in fecal pellets in our study, 3.1 to $22.9 \mathrm{mgC} \mathrm{m}^{-2} \mathrm{~d}^{-1}$, is also consistent with summer mean carbon flux reported from fecal pellets collected in a trap (of the same model) in the Ross Sea, which ranged from 2.4 to $15.6 \mathrm{mgC} \mathrm{m}^{-2} \mathrm{~d}^{-1}$ with a maximum of $28.4 \mathrm{mgC} \mathrm{m}^{-2} \mathrm{~d}^{-1}$ (Smith et al. 2011).

As suggested by several samples in which pellets constituted $>100 \%$ of the total POC flux, any error likely tends toward overestimation of pellet contribution to flux (although both total trap POC and pellet 
POC flux is likely underestimated; see next paragraph). There is high variability in krill fecal pellet carbon content and density due to diet and seasonal changes in krill digestion, producing pellets with density ranging from 1038 to $1391 \mathrm{~kg} \mathrm{~m}^{-3}$ (Atkinson et al. 2012). We accounted for variation in carbon:volume ratio between major pellet types (see 'Materials and methods'). However, using the same carbon:volume conversion for all pellets within each type, regardless of season or 'compactness', could lead to overestimation of fecal pellet contribution to carbon flux. High-flux summer samples required 4 to 8 splits before analysis due to the high density of fecal pellets, potentially introducing additional error (due to compounding splitting errors) compared to lower pellet density samples. Variation in fecal pellet flux is a likely characteristic throughout the WAP due to the patchy nature of krill swarms (Atkinson et al. 2012). Since the WAP time-series sediment trap measures flux at just 1 location, the spatial variability of krill, and other zooplankton, could be a limiting factor of our sampling design.

Finally, a recent short-term trap comparison during summer off the WAP indicated that the moored conical sediment trap used in our study collected up to 30 times lower flux when compared to a drifting cylindrical trap at $150 \mathrm{~m}$ and ${ }^{234} \mathrm{Th}$ disequilibrium profiles (Buesseler et al. 2010). This undercollection is likely due to trap hydrodynamics, as horizontal flow over relatively shallow-moored, conical sediment traps can resuspend particles before reaching the bottom of the trap (Alldredge et al. 1990, Buesseler et al. 2007a). While the actual magnitude of the fecal pellet POC flux would also be underestimated as a result, particle sorting is unlikely a source of error for the moored conical trap, as microscopic analysis of particles from both drifting and moored traps yielded similar particle types (Buesseler et al. 2010). Furthermore, sinking particles collected in polyacrylamide gel traps were predominantly cylindrical and ovoid pellets (McDonnell \& Buesseler 2010), reflecting the major pellet types we found in our sediment trap samples.

\section{Other components of the flux}

Other particulate matter such as phytodetritus and fecal fluff occurred in trap samples in addition to intact fecal pellets. Phytodetritus was more prevalent in winter $(74 \%$ of samples with obvious phytodetritus) than in summer (31\%), when fecal pellets dominated flux. However, in winter the total POC flux was low, such that the phytodetritus present in winter samples would be equivalent to only a small fraction of the flux in summer that is primarily pellets. It appears that in this region, zooplankton are the primary exporters of POC by grazing and repackaging phytoplankton as pellets during the phytoplankton bloom period. This has implications for the biological pump in the WAP. Phytodetritus with sinking rates of 100 to $150 \mathrm{~m} \mathrm{~d}^{-1}$ would take longer than fecal pellets of krill (300 $\mathrm{m} \mathrm{d}^{-1}$ ) or other zooplankton to reach the deep sea (Lampitt 1985, Turner 2002) and potentially would be attenuated more rapidly than pellets. However, we expected that more phytodetritus would be present in the trap samples in summer, as on average a small fraction of the primary production along the WAP appears to be grazed by macrozooplankton in summer (Bernard et al. 2012), when the highest phytoplankton biomass is found.

Fecal fluff, or degraded fecal pellets, was prevalent in trap samples year-round, associated with large, less compact pellets. Coprorhexy (fragmentation of pellets by zooplankton) and coprophagy (consumption of pellets) are known to contribute to attenuation of fecal pellet flux in the Antarctic (González 1992, Suzuki et al. 2003, Sampei et al. 2009). Long, cylindrical krill pellets are especially prone to fragmentation by copepods and other zooplankton, thus slowing sinking rates (Lampitt et al. 1990, Sampei et al. 2009). Coprophagous degradation of fecal pellets by copepods is documented in polar regions, especially in winter when sea ice limits phytoplankton growth (González \& Smetacek 1994, Suzuki et al. 2003, Sampei et al. 2009, Møller et al. 2011). It is difficult to quantify fecal fluff; thus, our estimate of the importance of fecal pellet $\mathrm{C}$ in total flux is likely underestimated (Wilson et al. 2008).

\section{Contribution of different taxa to fecal pellet flux}

Zooplankton abundance and distribution along the WAP has been routinely quantified during summer (January) since 1993 by the Palmer LTER (Ross et al. 2008, Bernard et al. 2012). More infrequently, other studies have quantified zooplankton distribution during other seasons (e.g., Southern Ocean Global Ocean Ecosystems Dynamics studies in fall and winter 2001 and 2002; Ashjian et al. 2004, Marrari et al. 2011). The dominant macrozooplankton along the WAP include krill, salps, pteropods, and copepods, with broad patterns in zooplankton community structure reflecting cross-shelf zones and latitude as well as water masses and sea ice conditions (Ashjian et al. 
2008, Ross et al. 2008, Ducklow et al. 2012). In summer, cross-shelf gradients result in higher abundance of krill inshore and over the continental shelf and of salps offshore at the shelf break (Ross et al. 2008, Bernard et al. 2012, Ducklow et al. 2012). In summer, large calanoid copepods are present but constitute $<10 \%$ of total macrozooplankton biomass (Bernard et al. 2012). In winter, zooplankton abundance is reduced and dominated by larval krill and copepods, with higher copepod abundance offshore (Ashjian et al. 2004). While further studies are needed to elucidate seasonal trends in zooplankton along the WAP, we can infer the contribution of different taxa to fecal pellet flux from seasonal fecal pellet analysis.

Krill fecal pellets contributed a monthly mean of $72 \%$ of total fecal pellet carbon flux, compared to copepod pellets $(22 \%)$ and salp pellets (6\%). Flux of krill and copepod pellets occurred almost exclusively in summer, whereas salp pellet flux was low and similar in summer and winter. These results reflect patterns of zooplankton distribution at the WAP marginal ice zone (Ross et al. 2008), with krill populations found over the shelf following sea ice retreat in the spring and summer months during the phytoplankton bloom (Quetin \& Ross 2001). The importance of krill fecal pellets to POC export in WAP waters, and in the Southern ocean in general (Le Fevre et al. 1998, Atkinson et al. 2012), is in contrast to non-polar regions in which krill pellets contribute similar or less to pellet flux than copepod pellets (Carroll et al. 1998, Wilson et al. 2008). Low carbon flux of copepod pellets resuls from a combination of (1) lower biomass of copepods during summer in the study area (Bernard et al. 2012) and (2) higher potential for pellets to be recycled in the upper mixed layer, since copepods can ingest fecal pellets or fragment them into smaller, slower-sinking particles (Lampitt et al. 1990, Le Fevre et al. 1998). Variability in zooplankton fecal pellet flux and, thus, the carbon export is also a function of variability in size (i.e., carbon content) of pellets produced by the different taxa. The median $\mathrm{C}$ content of the different pellet types varied greatly, from small copepod $\left(0.04 \mu \mathrm{gC}\right.$ pellet $\left.^{-1}\right)$ to krill $(0.2 \mu \mathrm{gC}$ pellet $\left.^{-1}\right)$ and large salp pellets $\left(1.0 \mu \mathrm{gC}\right.$ pellet $\left.^{-1}\right)$. The median and mean carbon content of all pellets measured in this study was 0.1 and $0.4 \mu \mathrm{gC}$ pellet $^{-1}$, respectively. In summer, when pellet flux was almost exclusively from krill, median carbon content was $0.12 \mu \mathrm{gC}$ pellet $^{-1}$. A similar study of sediment trap samples collected during summer in the North Pacific Ocean from $150 \mathrm{~m}$ depth reports a median carbon content of $0.036 \mu \mathrm{gC}$ pellet $^{-1}$ in the oligotro- phic subtropical gyre and $0.170 \mu \mathrm{gC}$ pellet $^{-1}$ in the mesotrophic subarctic (Wilson et al. 2008). Thus, carbon content generally increases in higher latitudes, reflecting differences in zooplankton community structure.

Given the increasing importance of salps along the WAP (Loeb et al. 1997, Pakhomov et al. 2002, Atkinson et al. 2004, Ross et al. 2008), and the large size of their pellets, we had predicted that salp pellets would be more prevalent in the trap. Salps are indiscriminate filter feeders with high feeding rates that result in high production of rapidly sinking pellets $\left(700 \mathrm{~m} \mathrm{~d}^{-1}\right.$; Phillips et al. 2009). These pellets have potential to significantly affect $C$ export when salps are abundant (Madin \& Deibel 1998, Pakhomov et al. 2002, Phillips et al. 2009). Although salps are increasingly expanding their distribution over the shelf (Steinberg et al. unpubl.), they still occur more regularly off the shelf break in open water (Ross et al. 1996, Pakhomov et al. 2002, Ross et al. 2008). Thus, the probability of collecting pellets from a salp bloom may simply be lower at the location of the trap over the shelf. In the Scotia Sea, krill pellets were also more prevalent than salp pellets (Atkinson et al. 2012). Atkinson et al. (2012) hypothesized that compact krill schools produce 'rain showers' of pellets that overwhelm the ability of detritivores to reprocess them. Furthermore, salp fecal pellets lack a peritrophic membrane that keeps crustacean pellets intact (Bruland \& Silver 1981, Caron et al. 1989), and may dissociate and become unrecognizable in traps.

Fecal pellets from some taxa might be underrepresented in the trap compared to the presence of these pellets in the water column. For example, the main macrozooplankton carnivores along the WAP are chaetognaths (Schnack-Schiel \& Mujica 1994, Ross et al. 2008), which can produce fecal pellets with carbon content similar to that of krill pellets (Giesecke et al. 2010). But chaetognath pellets tend to float in the water column, as they contain buoyant lipids, and likely for this reason are not abundant in sediment trap samples (Dilling \& Alldredge 1993, Wilson et al. 2008, Giesecke et al. 2010). Furthermore, chaetognath fecal pellets are loosely packaged and, thus, may be more susceptible to bacterial degradation (Dilling \& Alldredge 1993, Giesecke et al. 2010). The major species of chaetognaths along the WAP are most abundant below $200 \mathrm{~m}$ (Schnack-Schiel \& Mujica 1994) and contribute $<2 \%$ to zooplankton biomass in the upper $120 \mathrm{~m}$ (Ross et al. 2008), further explaining the absence of chaetognath fecal pellets in our samples. 


\section{The changing Antarctic climate and fecal pellet carbon export}

Interannual differences in the length, timing, and extent of sea ice cover may affect the magnitude and timing of zooplankton fecal pellets contributing to POC flux in the WAP and may be used to infer possible effects of long-term changes in the zooplankton community on export. The 2005 to 2006 summer season had the highest fluxes in both total POC and fecal pellet POC of the $5 \mathrm{yr}$ we analyzed. When compared to satellite-derived sea ice cover over the Palmer LTER sediment trap mooring (Stammerjohn et al. 2008, Ducklow et al. 2012), this peak corresponds to a year with prolonged sea ice due to earlier advance and later retreat, $125 \mathrm{~d}$ longer than summer 2007 to 2008, which had the lowest summer POC flux. In addition, in 2005, the Palmer LTER regional sea ice extent, annually averaged, was $\sim 4 \times 10^{4} \mathrm{~km}^{2}$ greater than sea ice cover in 2007 (S. Stammerjohn, pers. comm.). As indicated in the longer-term data set of total POC flux, peak POC flux from the latter part of the time series, 1998 to 2009, is occurring $\sim 40$ d later than that from 1993 to 1997 (Ducklow et al. 2008). This may be due to a decrease in duration and magnitude of winter sea ice (Ducklow 2008, Stammerjohn et al. 2008, Ducklow et al. 2012), although there is currently no evidence for a significant relationship between flux and sea ice. As the bulk of the summer POC flux is in the form of zooplankton fecal pellets, this delay in peak flux is likely a result of a change in zooplankton population dynamics, and in food web transfer, that remains to be elucidated.

There has been a shift in the relative abundance of euphausiids and salps in the Southern Ocean, including the western Antarctic Peninsula, with a decline in krill and increase in salps as a result of a decrease in winter sea ice (Pakhomov et al. 2002, Atkinson et al. 2004, Steinberg et al. unpubl.). A decrease in krill populations with a subsequent increase in salps has major implications not only for the survival of Antarctic top predators (Le Fevre et al. 1998, Quetin \& Ross 2001, Atkinson et al. 2004, Steinberg et al. 2009, Ducklow et al. 2012) but also for export. Our results indicate that over the northern shelf of the WAP, krill fecal pellets are the dominant contributor to POC flux. While salp fecal pellets were more rare components of the flux, they can contain 100 times more carbon than krill pellets and sink more rapidly. In the winter months where we observed salp pellets, they contributed to 5 to $66 \%$ of total export. Thus, a continuing expansion of salps over the WAP continental shelf due to climate change could result in a significant change in the carbon export system. Carbon export may be enhanced but also more sporadic, due to the ephemeral nature of salp blooms. An alternative hypothesis is that as the internal mucous feeding net of salps becomes clogged in dense phytoplankton blooms (Harbison et al. 1986), salps may be unable to repackage carbon as pellets as efficiently as krill, resulting in increasing phytodetritus export and microbial activity (Le Fevre et al. 1998).

\section{CONCLUSIONS}

Zooplankton, primarily krill, fecal pellets are the major contributor to carbon export over the WAP continental shelf. We saw less evidence of salp contribution to export but expect that salps will become increasingly important in the future, even over the shelf, as climate change continues to affect the WAP ecosystem (Ducklow et al. 2012). The WAP time series sediment trap is just one location in the northern sector of the Palmer LTER study grid. A comparison trap located in the southern part of the study grid, where there is still currently perennial sea ice, could provide valuable insight into the state of the WAP biological pump prior to climate warming. Employing additional flux measurement technologies (i.e., in situ cameras and polyacrylamide gels; McDonnell \& Buesseler 2010) would also more fully illuminate the role of zooplankton in export in the WAP.

Acknowledgements. We thank the captain, officers, and crew of the ARSV 'Laurence M. Gould' and Raytheon Polar Services scientific support personnel for their help with sediment trap deployment and recovery during the Palmer LTER cruises. We thank M. Erikson for the sediment trap sample CHN analyses. We are grateful to J. Cope for providing advice on data analyses, to K. Ruck and J. Dryer for fecal pellet CHN analysis, and to S. Stammerjohn for providing unpublished sea ice data. This study was funded by the National Science Foundation Office of Polar Programs (OPP0823101). Additional funding to support M. Gleiber's participation on a Palmer LTER cruise was provided by A. G. 'Casey' Duplantier Jr. and the 1st Advantage Federal Credit Union of Newport News, VA, USA. This is contribution number 3254 from the Virginia Institute of Marine Science.

\section{LITERATURE CITED}

Alldredge A, Granata T, Gotschalk C, Dickey T (1990) The physical strength of marine snow and its implications for particle disaggregation in the ocean. Limnol Oceanogr 35:1415-1428

Anderson V (1998) Salp and pyrosomid blooms and their importance in biogeochemical cycles. In: Bone Q (ed) 
The biology of pelagic tunicates. Oxford University Press, Oxford, p 125-137

Ashjian CJ, Rosenwaks GA, Wiebe PH, Davis CS and others (2004) Distribution of zooplankton on the continental shelf off Marguerite Bay, Antarctic Peninsula, during austral Fall and Winter, 2001. Deep-Sea Res II 51:2073-2098

Atkinson A, Siegel V, Pakhomov E, Rothery P (2004) Longterm decline in krill stock and increase in salps within the Southern Ocean. Nature 432:100-103

> Atkinson A, Schmidt K, Fielding S, Kawaguchi S, Geissler PA (2012) Variable food absorption by Antarctic krill: relationships between diet, egestion rate and the composition and sinking rates of their fecal pellets. Deep-Sea Res II 59-60:147-158

> Bernard KS, Steinberg DK, Schofield OME (2012) Summertime grazing impact of the dominant macrozooplankton off the western Antarctic Peninsula. Deep-Sea Res I 62: 111-122

Bruland K, Silver M (1981) Sinking rates of fecal pellets from gelatinous zooplankton (Salps, Pteropods, Doliolids). Mar Biol 63:295-300

Buesseler KO, Antia AN, Chen M, Fowler SW and others (2007a) An assessment of the use of sediment traps for estimating upper ocean particle fluxes. J Mar Res 65: 345-416

Buesseler KO, Lamborg CH, Boyd PW, Lam PJ and others (2007b) Revisiting carbon flux through the ocean's twilight zone. Science 316:567-570

Buesseler KO, McDonnell AMP, Schofield OME, Steinberg DK, Ducklow HW (2010) High particle export over the continental shelf of the west Antarctic Peninsula. Geophys Res Lett 37:L22606

> Caron D, Madin L, Cole J (1989) Composition and degradation of salp fecal pellets: implications for vertical flux in oceanic environments. J Mar Res 47:829-850

> Carroll ML, Miquel J, Fowler SW (1998) Season patterns and depth-specific trends of zooplankton fecal pellet fluxes in the northwestern Mediterranean Sea. Deep-Sea Res 45:1303-1318

Dilling L, Alldredge AL (1993) Can chaetognath fecal pellets contribute significantly to carbon flux? Mar Ecol Prog Ser 92:51-58

$>$ Ducklow HW (2008) Long-term studies of the marine ecosystem along the west Antarctic Peninsula. Deep-Sea Res II 55:1945-1948

Ducklow HW, Steinberg DK, Buesseler KO (2001) Upper ocean carbon export and the biological pump. Oceanography 14:50-58

Ducklow HW, Erikson M, Kelly J, Montes-Hugo M and others (2008) Particle export from the upper ocean over the continental shelf of the west Antarctic Peninsula: a longterm record, 1992-2007. Deep-Sea Res II 55:2118-2131

Ducklow H, Clarke A, Dickhut R, Doney SC and others (2012) The marine system of the western Antarctic Peninsula. In: Rogers AD, Johnston NM, Murphy EJ, Clarke A (eds) Antarctic ecosystems: an extreme environment in a changing world. Blackwell, London, p 121-159

Fowler SW, Small LF (1972) Sinking rates of euphausiid fecal pellets. Limnol Oceanogr 17:293-296

> Gauld DT (1957) A peritrophic membrane in calanoid copepods. Nature 179:325-326

Giesecke R, González HE, Bathmann U (2010) The role of the chaetognath Sagitta gazellae in the vertical carbon flux of the Southern Ocean. Polar Biol 33:293-304
González HE (1992) The distribution and abundance of krill faecal material and oval pellets in the Scotia and Weddell Seas (Antarctica) and their role in particle flux. Polar Biol 12:81-91

> González HE, Smetacek V (1994) The possible role of the cyclopoid copepod Oithona in retarding vertical flux of zooplankton fecal material. Mar Ecol Prog Ser 113: 233-246

> Harbison GR, McAlister VL, Gilmer RW (1986) The response of the salp, Pegea confoederata, to high levels of particulate material: starvation in the midst of plenty. Limnol Oceanogr 31:371-382

Hidaka K, Kawaguchi K, Murakami M, Takahashi M (2001) Downward transport of organic carbon by diel migratory micronekton in the western equatorial Pacific: its quantitative and qualitative importance. Deep-Sea Res I 48: 1923-1939

> Honjo S, Francois R, Manganini S, Dymond J, Collier R (2000) Particle fluxes to the interior of the Southern Ocean in the western Pacific sector along $170^{\circ} \mathrm{W}$. DeepSea Res II 47:3521-3548

Huskin I, Viesca L, Anadon R (2004) Particle flux in the subtropical Atlantic near the Azores: influence of mesozooplankton. J Plankton Res 26:403-415

Karl DM, Dore JE, Hebel DV, Winn C (1991a) Procedures for particulate carbon, nitrogen, phosphorus and total mass analyses used in the US-JGOFS Hawaii Ocean timeseries program. In: Hurd DC, Spencer DW (eds) Marine particles: analysis and characterization. American Geophysical Union, Washington, DC, p 71-77

Karl DM, Tilbrook BD, Tien G (1991b) Seasonal coupling of organic matter production and particle flux in the western Bransfield Strait, Antarctica. Deep-Sea Res 38: 1097-1126

> Köster M, Sietmann R, Meuche A, Paffenhöffer G (2011) The ultrastructure of a doliolid and a copepod fecal pellet. J Plankton Res 33:1538-1549

> Lampitt RS (1985) Evidence for the seasonal deposition of detritus to the deep-sea floor and its subsequent resuspension. Deep-Sea Res 32:885-897

Lampitt RS, Noji T, von Bodungen B (1990) What happens to zooplankton faecal pellets? Implication for material flux. Mar Biol 104:15-23

Le Fevre J, Legendre L, Rivkin RB (1998) Fluxes of biogenic carbon in the Southern Ocean: roles of large microphagous zooplankton. J Mar Syst 17:325-345

Loeb V, Siegel V, Holm-Hansen O, Hewitt R, Fraser W, Trivelpiece W, Trivelpiece S (1997) Effects of sea-ice extent and krill or salp dominance on Antarctic food web. Nature 387:897-900

Madin LP, Deibel D (1998) Feeding and energetics of Thaliacea. In: Bone Q (ed) The biology of pelagic tunicates. Oxford University Press, Oxford, p 81-103

Marrari M, Daly KL, Timonin A, Semenova T (2011) The zooplankton of Marguerite Bay, western Antarctic Peninsula - Part I: abundance, distribution, and population response to variability in environmental conditions. Deep-Sea Res II 58:1599-1653

McDonnell AMP, Buesseler KO (2010) Variability in the average sinking velocities of marine particles. Limnol Oceanogr 55:2085-2096

Møller EF, Borg CMA, Jonasdottir SH, Satapoomin S, Jaspers C, Nielsen TG (2011) Production and fate of copepod fecal pellets across the southern Indian Ocean. Mar Biol 158:677-688 
Montes-Hugo M, Doney SC, Ducklow HW, Fraser W, Martinson D, Stammerjohn SE, Schofield O (2009) Recent changes in phytoplankton communities associated with rapid regional climate change along the western Antarctic Peninsula. Science 323:1470-1473

Montes-Hugo M, Sweeney C, Doney SC, Ducklow H and others (2010) Seasonal forcing of summer dissolved inorganic carbon and chlorophyll $a$ on the western shelf of the Antarctic Peninsula. J Geophys Res 115:C03024

Pakhomov EA, Froneman PW, Perissinotto R (2002) Salp/ krill interactions in the Southern Ocean: spatial segregation and implications for the carbon flux. Deep-Sea Res II 49:1881-1907

Patonai K, El-Shaffey H, Paffenhöffer G (2011) Sinking velocities of fecal pellets of doliolids and calanoid copepods. J Plankton Res 33:1146-1150

Phillips B, Kremer P, Madin LP (2009) Defecation by Salpa thompsoni and its contribution to vertical flux in the Southern Ocean. Mar Biol 156:455-467

Quetin LB, Ross RM (2001) Environmental variability and its impact on the reproductive cycle of Antarctic krill. Am Zool 41:74-89

Richardson AJ (2008) In hot water: zooplankton and climate change. ICES J Mar Sci 65:279-295

Ross RM, Quetin LB, Lascara CM (1996) Distribution of Antarctic krill and dominant zooplankton west of the Antarctic Peninsula. In: Ross RM, Hofmann EE, Quetin LB (eds) Foundations for ecological research west of the Antarctic Peninsula. Antarct Res Ser 70:199-217

Ross RM, Quetin LB, Martinson DG, Iannuzzi RA, Stammerjohn SE, Smith RC (2008) Palmer LTER: patterns of distribution of five dominant zooplankton species in the epipelagic zone west of the Antarctic Peninsula, 19932004. Deep-Sea Res II 55:2086-2105

Saba GK, Steinberg DK (2012) Abundance, composition, and sinking rates of fish fecal pellets in the Santa Barbara Channel. Scientific Reports 2:1-6

Sampei M, Forest A, Sasaki H, Hattori H, Makabe R, Fukuchi M, Fortier L (2009) Attenuation of the vertical flux of copepod fecal pellets under Arctic sea ice: evidence for an active detrital food web in winter. Polar Biol 32:225-232

Schnack-Schiel SB, Mujica A (1994) The zooplankton of the Antarctic Peninsula region. In: El-Sayed SZ (ed) Southern Ocean ecology: the biomass perspective. Cambridge University Press, Cambridge, p 79-92

Smith WO, Shields AR, Dreyer JC, Peloquin JA, Asper V (2011) Interannual variability in vertical export in the Ross Sea: magnitude, composition, and environmental correlates. Deep-Sea Res II 58:147-159

Stammerjohn SE, Martinson DG, Smith RC, Iannuzzi RA (2008) Sea ice in the western Antarctic Peninsula region:

Editorial responsibility: Anna Pasternak, Moscow, Russia spatio-temporal variability from ecological and climate change perspectives. Deep-Sea Res II 55:2041-2058

- Steinberg DK, Van Mooy BAS, Buesseler KO, Boyd PW, Kobari T, Karl DM (2008) Bacterial vs. zooplankton control of sinking particle flux in the ocean's twilight zone. Limnol Oceanogr 53:1327-1338

Steinberg DK, Ruck KE, Price LM, Gleiber MG, Cope JC, Ducklow HW (2009) Zooplankton export of organic matter in the west Antarctic Peninsula. In: Long-Term Ecological Research (LTER) All Scientists Meeting 2009 Abstracts, Estes Park, CO

> Steinberg DK, Lomas MW, Cope JC (2012) Long-term increase in mesozooplankton biomass in the Sargasso Sea: linkage to climate and implications for food web dynamics and biogeochemical cycling. Global Biogeochem Cycles 26:GB1004

Suzuki H, Sasaki H, Fukuchi M (2003) Loss processes of sinking fecal pellets of zooplankton in the mesopelagic layers of the Antarctic marginal ice zone. J Oceanogr 59: 809-818

Turner JT (2002) Zooplankton fecal pellets, marine snow and sinking phytoplankton blooms. Aquat Microb Ecol 27:57-102

> Urrère MA, Knauer GA (1981) Zooplankton fecal pellet fluxes and vertical transport of particulate organic material in the pelagic environment. J Plankton Res 3:369-387

> Vaughan DG, Marshall GJ, Connolley WM, Parkinson C and others (2003) Recent rapid regional climate warming on the Antarctic Peninsula. Clim Change 60:243-274

> Wassmann P (1997) Retention versus export food chains: processes controlling sinking loss from marine pelagic systems. Hydrobiologia 363:29-57

- Wassmann P, Ypma JE, Tselepides A (2000) Vertical flux of faecal pellets and microplankton on the shelf of the oligotrophic Cretan Sea (NE Mediterranean Sea). Prog Oceanogr 46:241-258

- Wefer G, Fischer G, Fuetterer D, Gersonde R (1988) Seasonal particle flux in the Bransfield Strait, Antarctica. Deep-Sea Res Part A 35:891-898

- Wexels Riser C, Wassmann P, Reigstad M, Seuthe L (2008) Vertical flux regulation by zooplankton in the northern Barents Sea during Arctic spring. Deep-Sea Res II 55: 2320-2329

Wilson SE, Steinberg DK, Buesseler KO (2008) Changes in fecal pellet characteristics with depth as indicators of zooplankton repackaging of particles in the mesopelagic zone of the subtropical and subarctic North Pacific Ocean. Deep-Sea Res II 55:1636-1647

Yoon WD, Kim SK, Han KN (2001) Morphology and sinking velocities of fecal pellets of copepod, molluscan, euphausiid, and salp taxa in the northeastern tropical Atlantic. Mar Biol 139:923-928

Submitted: January 13, 2012; Accepted: August 26, 2012 Proofs received from author(s): November 28, 2012 